\section{Response of Potted Sunflower Cultivars to Daminozide Foliar Sprays and Paclobutrazol Drenches}

\author{
Brian E. Whipker ${ }^{1}$ and \\ Ingram M cCall
}

AdDITIONAL INDEX WORDS. H elianthus annuus, growth retardant

Summary. Plant growth retardant (PG R) foliar sprays of daminozide at 4,000 or $8,000 \mathrm{mg} \cdot \mathrm{L}^{-1}(\mathrm{ppm})$ and paclobutrazol drenches of 2 or $4 \mathrm{mg}$ a.i. per pot were applied to 'Big Smile', 'Pacino', 'Sundance Kid', 'Sunspot', and 'T eddy Bear' pot sunflowers (H dianthusannuus L.) to compare their chemical height control. Plant height varied among the cultivars due to genetic variation. The percentage reduction in plant height from the untreated control only was significant at the PG R level, indicating similar responses of all five cultivars to each PG R rate. Paclobutrazol drenches at 2 $\mathrm{mg}$ and daminozide foliar sprays at 4,000 or $8,000 \mathrm{mg} \cdot \mathrm{L}^{-1}$ reduced plant height by about $24 \%$ when compared to the control. Paclobutrazol drenches at $4 \mathrm{mg}$ produced plants that were $33 \%$ shorter than the control. Plant diameter of 'Big Smile', 'Pacino', or 'Sundance Kid' was unaffected by daminozide, whereas 'Sunspot' plants were smaller than the controls.

Paclobutrazol drenches at 2 or $\mathbf{4} \mathbf{~ m g}$ decreased plant diameter for all cultivars except 'T eddy Bear', with the reduction being greater as paclobutrazol drench rates increased.

D epartment of H orticultural Science, B ox 7609, N orth Carolina State U niversity, Raleigh, N C 27695-7609.

This research was funded in part by the $\mathrm{N}$ orth $\mathrm{C}$ arolina Agricultural Research Service (NCARS), Raleigh, NC 27695-7643. U se of trade names in this publication doesnot imply endorsement by the N CARS of products named nor criticism of similar ones not mentioned. Thanks to Ball, Benary, Fred C. Gloeckner, and Sakata Seed Companies for supplying seed, Fafard for supplying the root substrate, and U niroyal Chemical $\mathrm{Co}$. for grant support. The cost of publishing this paper was defrayed in part by payment of page charges. Under postal regulations, this paper therefore must be hereby marked advertisment solely to indicate this fact.

${ }^{1}$ Corresponding author.

Hortlechnology • J anuary-M arch 2000 10(1)
The number of inflorescence buds increased by $\geq 18 \%$ with the use of daminozide sprays, while paclobutrazol drenches at 2 or $\mathbf{4} \mathbf{~ m g ~ h a d ~ n o ~ e f f e c t ~}$ when compared to the untreated control. Paclobutrazol drenches of 2 or $4 \mathrm{mg}$ offer the economic advantage to growers of increased plant density on greenhouse benches, while plants treated with daminozide had an increased bud count but would require a greater amount of bench space.

$\mathrm{P}$

lant growth retardants (PGRs) are commonly applied to container-grown plants to control stem elongation and produce compact plants (T ayama et al., 1992). $M$ arketable sized 'Pacino' potted sunflower plants were produced with daminozide (2,2-dimethylhydrazide) (B-N ine, Uniroyal Chemical, M iddlebury, Conn.) foliar sprays of 4000 to $8000 \mathrm{mg} \cdot \mathrm{L}^{-1}$ (ppm) (Whipker and Dasoju, 1998) or with paclobutrazol ((2R, 3R +2S, 3S)-1-(4-chlorophenyl)4,4-dimethyl-2-(1,2,4-triazol-1-yl) pentan-3-ol)) (Bonzi, U niroyal C hemical, M iddlebury, Conn.) drench doses of 2 to $4 \mathrm{mg}$ per pot (Dasoju et al., 1998). H owever, 'Pacino' was the only cultivar used in establishing the recommended PGR rates for potted sunflowers. Growth of other commercially availablesunflower cultivarsvariesgreatly from 'Pacino'. Therefore, thisstudy was conducted to determine if PGR rates recommended for height control of 'Pacino' wereappropriatefor 'BigSmile', 'Sundance Kid', 'Sunspot', and 'T eddy Bear' pot sunflowers.

\section{Materials and methods}

Sunflower seeds of 'Big Smile', 'Pacino', 'SundanceKid', 'Sunspot', and 'T eddy Bear' were sown into cell packs $[8 \times 4 \times 5.5 \mathrm{~cm}$ cells $(3.1 \times 1.6 \times 2.2$ inch)] on 14 Jan. 1998. O n 28 Jan., seedlings were transplanted into $1.2-\mathrm{L}$ (0.3-gal) [15-cm (6-inch) diameter] round plastic pots, except $750-\mathrm{mL}$ (0.2gal) [ $12 \mathrm{~cm}$ diameter ( 5 inch)] containers were used for 'Big Smile'. The root substrate was F afard 4P (Fafard, Anderson, S.C.). Plants were fertilized at each watering with $150 \mathrm{mg} \cdot \mathrm{L}^{-1} \mathrm{~N}$ from Excel 15-5-15 Cal-M ag (Scotts, M arysville, O hio) (15N-2.1P-12.5K). Greenhouse day/ night set points were $24 / 18{ }^{\circ} \mathrm{C}$ $\left(75 / 65^{\circ} \mathrm{F}\right)$. The plants were grown under natural daylength. The PGRs were applied $20 \mathrm{~d}$ after potting: daminozide foliar sprays at 4,000 or $8,000 \mathrm{mg} \cdot \mathrm{L}^{-1}$ using a volume of 204
$\mathrm{mL} \cdot \mathrm{m}^{-2}\left(0.5 \mathrm{gal} / 100 \mathrm{ft}^{2}\right)$; paclobutrazol drenchesat 2 or $4 \mathrm{mg}$ a.i./ pot using 133 $\mathrm{mL}$ ( $4.5 \mathrm{fl} \mathrm{oz}$ ) of solution per pot; or an untreated control. The experiment was a completely randomized design with eight single-plant replications of the five treatments. At anthesis, the number of days from seeding until anthesis, total plant height (measured from the pot rim to the uppermost part of the inflorescence), inflorescence and plant diameter (measured at the widest dimension and turned $90^{\circ}$, and averaged), and the number of inflorescence buds in addition to the primary inflorescence were recorded. D ata were tested by analysis of variance by general linear model (SAS I nstitute, Cary, N.C.) and means were separated by least significant differences at $P \leq 0.05$.

\section{Results and discussion}

Total plant height was significant for the PG R x cultivar interaction ( T able 1). Plant height varied by cultivar, with theheight of theuntreated control plants increasing ( shortest to tallest) from 'Big Smile', 'Sunspot', 'Teddy Bear', 'SundanceK id', to 'Pacino'. D ifferences in plant height among the cultivars was expected dueto genetic variation. $\mathrm{H}$ owever, the percentage reduction in plant height from the untreated control was only significant at the PGR level, indicating similar responses of the five cultivars to each PGR rate (Table 2 ). Paclobutrazol drenches at $2 \mathrm{mg}$ and daminozide foliar sprays at 4,000 or $8,000 \mathrm{mg}^{\cdot \mathrm{L}^{-1}}$ reduced plant height by about 24\%, whereas paclobutrazol drenches at $4 \mathrm{mg}$ reduced plant height by $33 \%$ compared to the control. The percentage height reduction with the 4 mg paclobutrazol drench for 'Pacino', 'Sundance Kid', 'Sunspot', and 'T eddy Bear' resulted in plants that were proportional to the pot size, but this rate was excessive for 'Big Smile'. Even though 'Big Smile' was the shortest cultivar utilized, the use of daminozide foliar spraysat 4,000 or $8,000 \mathrm{mg} \cdot \mathrm{L}^{-1}$ or paclobutrazol drenchesat $2 \mathrm{mg}$ reduced the degree of internodeelongation compared to the untreated plants. These results suggest that the optimal PGR rates recommended for height control of 'Pacino' (D asoju et al., 1998; Whipker and D asoju, 1998) were applicable to other pot sunflower cultivars.

Plant diameter of untreated control plants of 'Pacino', 'Sundance Kid', 'T eddy Bear', and 'Sunspot' were similar, but 'Big Smile' was the smallest 
T able 1. Effect of daminozide foliar spray or paclobutrazol drench applications on subsequent growth and flowering of five cultivars of potted sunflowers $\left(1 \mathrm{mg} \cdot \mathrm{L}^{-1}=1 \mathrm{ppm}, 28,350 \mathrm{mg}=1.0 \mathrm{oz}, 2.54 \mathrm{~cm}=1.0\right.$ inch).

\begin{tabular}{|c|c|c|c|c|c|}
\hline \multirow{2}{*}{$\begin{array}{l}\text { Cultivar and } \\
\text { plant growth } \\
\text { regulator treatment }\end{array}$} & \multirow{2}{*}{$\begin{array}{c}\text { Plant ht } \\
(\mathrm{cm})\end{array}$} & \multicolumn{2}{|c|}{ Plant diam } & \multicolumn{2}{|c|}{ Days until anthesis } \\
\hline & & $\mathbf{c m}$ & $\%$ of control & days & $\%$ of control \\
\hline \multicolumn{6}{|l|}{ Big Smile } \\
\hline Control & 19.8 & 37.1 & 100 & 52.1 & 100 \\
\hline $4,000 \mathrm{mg} \cdot \mathrm{L}^{-1} \mathrm{D}$ aminozide & 14.2 & 36.8 & 99 & 56.1 & 108 \\
\hline $8,000 \mathrm{mg} \cdot \mathrm{L}^{-1} \mathrm{D}$ aminozide & 15.0 & 38.0 & 102 & 56.0 & 108 \\
\hline 2 mg Paclobutrazol & 14.6 & 33.2 & 90 & 53.0 & 102 \\
\hline 4 mg Paclobutrazol & 12.7 & 30.7 & 83 & 53.4 & 103 \\
\hline \multicolumn{6}{|l|}{ Pacino } \\
\hline Control & 59.7 & 45.0 & 100 & 76.6 & 100 \\
\hline $4,000 \mathrm{mg} \cdot \mathrm{L}^{-1} \mathrm{D}$ aminozide & 53.9 & 43.8 & 97 & 77.9 & 102 \\
\hline $8,000 \mathrm{mg} \cdot \mathrm{L}^{-1} \mathrm{D}$ aminozide & 54.3 & 44.5 & 99 & 78.9 & 103 \\
\hline 2 mg Paclobutrazol & 50.2 & 39.2 & 87 & 79.1 & 103 \\
\hline 4 mg Paclobutrazol & 44.4 & 35.8 & 80 & 78.1 & 102 \\
\hline \multicolumn{6}{|l|}{ Sundance Kid } \\
\hline Control & 49.8 & 43.1 & 100 & 59.8 & 100 \\
\hline $4,000 \mathrm{mg} \cdot \mathrm{L}^{-1} \mathrm{D}$ aminozide & 38.4 & 41.6 & 97 & 62.9 & 105 \\
\hline $8,000 \mathrm{mg} \cdot \mathrm{L}^{-1} \mathrm{D}$ aminozide & 38.5 & 43.5 & 101 & 63.6 & 106 \\
\hline 2 mg Paclobutrazol & 41.7 & 38.6 & 90 & 62.3 & 104 \\
\hline 4 mg Paclobutrazol & 31.2 & 34.3 & 80 & 61.9 & 104 \\
\hline \multicolumn{6}{|l|}{ Sunspot } \\
\hline Control & 36.3 & 41.1 & 100 & 60.9 & 100 \\
\hline $4,000 \mathrm{mg} \cdot \mathrm{L}^{-1} \mathrm{D}$ aminozide & 26.5 & 36.5 & 89 & 63.4 & 104 \\
\hline $8,000 \mathrm{mg} \cdot \mathrm{L}^{-1} \mathrm{D}$ aminozide & 27.5 & 34.7 & 84 & 66.6 & 109 \\
\hline $2 \mathrm{mg}$ Paclobutrazol & 25.2 & 34.4 & 82 & 61.1 & 100 \\
\hline 4 mg Paclobutrazol & 25.2 & 33.1 & 80 & 60.8 & 100 \\
\hline \multicolumn{6}{|l|}{ T eddy B ear } \\
\hline Control & 40.1 & 43.1 & 100 & 67.4 & 100 \\
\hline $4,000 \mathrm{mg} \cdot \mathrm{L}^{-1} \mathrm{D}$ aminozide & 26.9 & 44.7 & 104 & 70.4 & 104 \\
\hline $8,000 \mathrm{mg} \cdot \mathrm{L}^{-1} \mathrm{D}$ aminozide & 25.0 & 49.0 & 114 & 70.6 & 105 \\
\hline 2 mg Paclobutrazol & 28.6 & 40.9 & 95 & 71.3 & 106 \\
\hline 4 mg Paclobutrazol & 24.8 & 40.9 & 95 & 71.8 & 107 \\
\hline Significance & $* *$ & $* * *$ & $* *$ & $* *$ & $* *$ \\
\hline $\operatorname{LSD}_{(\alpha \leq 0.05)}$ & 4.5 & 3.1 & 7.4 & 2.2 & 3.6 \\
\hline
\end{tabular}

$\overline{{ }^{*}, * * *}$ Significant at $\mathrm{P} \leq 0.01$ or 0.001 , respectively, for the plant growth regulator $\times$ cultivar interaction.

(Table 1). Plant diameter was unaffected by daminozidespraysat 4,000 or $8,000 \mathrm{mg} \cdot \mathrm{L}^{-1}$ for 'Big Smile', 'Pacino', or 'Sundance Kid' relative to the untreated controls. 'Sunspot' plantstreated with daminozide were smaller than the control. 'Teddy Bear' plants sprayed with $8,000 \mathrm{mg} \cdot \mathrm{L}^{-1}$ of daminozide had a significantly larger plant diameter than thecontrol. Paclobutrazol drenchesat 2 or $4 \mathrm{mg}$ decreased plant diameter for all cultivars except 'T eddy B ear', with the reduction being greatest at $4 \mathrm{mg}$. At the ratesused, paclobutrazol drenches offer an economicadvantageover daminozide sprays for commercial greenhouse operations in producing smaller diameter plants which can be spaced closer. This spreads out the cost-per-square-footper-week of the greenhouse operation over a larger number of plants and resultsin lower per-pot production costs.

Thepercentageof budswhen compared to the untreated control was only significant at thePG R level. D aminozide increased the number of buds by $\geq 18 \%$ while paclobutrazol drenches had no effect (Table 2). M orefloriferous plants would be a valuable characteristic for growers producing plants for retail sales where a wider plant spacing required with the use of daminozide could be economically justified.

The number of days until anthesis

was significant for the cultivar $\times$ PG interaction (Table 1). For 'Big Smile' and 'Sunspot', daminozide sprays delayed flowering, but paclobutrazol drencheshad no effect, when compared to the untreated control. All the PGRs delayed flowering of 'T eddy Bear'. E ven though the delay in flowering caused by the use of PG R s was statistically signifi-

Table 2. Effect of daminozide foliar spray or paclobutrazol drench applications on the percentage height reduction and percentage bud count of potted sunflowers $\left(1 \mathrm{mg} \cdot \mathrm{L}^{-1}=1 \mathrm{ppm}, 28,350 \mathrm{mg}=1.0 \mathrm{oz}\right)$.

\begin{tabular}{lcc}
\hline $\begin{array}{l}\text { Plant growth } \\
\text { regulator } \\
\text { treatment }\end{array}$ & $\begin{array}{c}\text { Plant ht } \\
\text { (\% of control) }\end{array}$ & $\begin{array}{c}\text { Inflorescence } \\
\text { bud count } \\
\text { (\% of control) }\end{array}$ \\
\hline Control & 100 & 100 \\
$4,000 \mathrm{mg} \cdot \mathrm{L}^{-1}$ D aminozide & 76 & 119 \\
$8,000 \mathrm{mg} \cdot \mathrm{L}^{-1} \mathrm{D}$ aminozide & 76 & 118 \\
$2 \mathrm{mg} \mathrm{Paclobutrazol}$ & 76 & 103 \\
$4 \mathrm{mg} \mathrm{Paclobutrazol}$ & 67 & 95 \\
Significance & $* * *$ & $*$ \\
$\mathrm{LSD}_{(\alpha \leq 0.05)}$ & 5.2 & 16.4 \\
${ }_{*, * * *}$ Significant at $\mathrm{P} \leq 0.05$ or 0.001, respectively $(\mathrm{n}=40)$ &
\end{tabular}


cant, the differences would not be detrimental to commercial greenhouse operations.

I nflorescence diameter varied only by cultivar, with the mean sizes ranging from (in cm): 'T eddy B ear' (10.2), 'Big Smile' (10.3), 'Sundance Kid' (10.5), 'Sunspot' (13.0), to 'Pacino' (14.0). This varied only slightly from earlier reportsin which daminozidefoliar sprays at 4,000 or $8,000 \mathrm{mg} \cdot \mathrm{L}^{-1}$ (Whipker and D asoju, 1998) or paclobutrazol drenches at $4 \mathrm{mg}$ (D asoju et al., 1998) resulted in a statistically smaller inflorescence $(5 \%$ to $12 \%$ ). Although inflorescence diameter was statistically smaller, the differences would not bea detrimental reduction to commercial growers.

\section{Conclusions}

The recommended PG $R$ rates derived from research with 'Pacino' are suitable for other commercially grown pot sunflower cultivars. Based on the cost of $\$ 70 / \mathrm{lb}(\$ 154 / \mathrm{kg})$, daminozide foliar sprays between 4,000 or 8,000 $\mathrm{mg} \cdot \mathrm{L}^{-1}$ would cost $\$ 0.01$ per $1.2-\mathrm{L}$ pot. Based on the cost of $\$ 110 / \mathrm{qt}$ ( $\$ 116 / \mathrm{L})$, a 2 mg paclobutrazol drench would cost $\$ 0.06$ per 1.2-L pot, which was six times more expensive than the daminozide foliar sprays. $\mathrm{H}$ eight control was similar with either daminozide foliar spraysat 4,000 or $8,000 \mathrm{mg} \cdot \mathrm{L}^{-1}$ or with paclobutrazol drenches of $2 \mathrm{mg}$. Paclobutrazol drenches of 2 or $4 \mathrm{mg}$ offer the economic advantage to growers of increased plant density on greenhousebenches, whileplantstreated with daminozidehad an increased bud count, but would require a greater amount of bench space. Growers should evaluate the trade-offs between the added costs of a paclobutrazol drench and labor costs of applying a drench versus the higher cost-per-square-foot-week of production space required for a daminozide foliar spray.

\section{Literature cited}

D asoju, S., M .E. Evans, and B.E. Whipker. 1998. Paclobutrazol drenches control growth of potted sunflowers. HortT echnology 8:235-237.

Tayama, H .K., R.A. Larson, P.A. H ammer, and T.J. Rolls (eds.). 1992. Tips on the use of chemical growth regulators on floriculture crops. O hio Florists' Assn., Columbus.

Whipker, B.E. and S. D asoju. 1998. Potted sunflower growth and flowering responses to foliar applications of daminozide, paclobutrazol, and uniconazole. $\mathrm{H}$ ortT echnology 8:86-88.

Horllechnology • J anuary-M arch 2000 10(1) 